\title{
Promoting the hybrid socio-technical approach for effective disaster risk reduction in developing countries
}

\author{
D. Karnawati ${ }^{1}$, T. F. Fathani ${ }^{2}$, W. Wilopo ${ }^{1}$, A. Setianto ${ }^{1}$ \\ \& B. Andayani ${ }^{3}$ \\ ${ }^{1}$ Department of Geological Engineering, Gadjah Mada University, \\ Indonesia \\ ${ }^{2}$ Department of Civil and Environmental Engineering, Gadjah Mada \\ University, Indonesia \\ ${ }^{3}$ Faculty of Psychology, Gadjah Mada University, Indonesia
}

\begin{abstract}
This paper highlights the importance of integrating social and technical approaches (which is the so-called "hybrid socio-technical approach") as one innovative and strategic program with respect to disaster risk reduction. Such a program is mainly based on multi-disciplinary action research to support the community empowerment program through public education. The technical approach was mainly conducted for geological and geotechnical investigation to analyze and predict susceptibility levels of the disaster prone area, as well as to develop an appropriate technology for hazard mapping and disaster early warning. Meanwhile, the social approach was necessary for analyzing and mapping the psycho-social conditions of the disaster prone area, and accordingly an appropriate strategy and program to implement the early warning technology can be formulated. Moreover, it is also important to establish a "community task force" as the driving power for landslide disaster risk reduction which can sustain the program at the village level.

Keywords: hybrid socio-technical system, indigenous technology, life and environmental protection, community empowerment.
\end{abstract}




\section{Introduction}

Indonesia is situated in such a dynamic geological region that it is frequently struck by various types of geological disasters such as earthquakes, tsunami, volcanic eruption, landslides and debris flood. Unfortunately, this region is occupied by a high density population, and those disasters continuously cause substantial death tolls, casualties, and socio-economical losses. According to [1], Indonesia has been struck by 6,632 events of natural disasters (mainly geological disasters), within the period of 1997 to 2009, with a total death toll of 151,277 people. Therefore, it is very important to urgently develop appropriate disaster management for life protection and environmental sustainability through the improvement of society resilience in such a disaster prone area.

\section{Problems in disaster risk reduction}

The development of a hazard map and the application of an appropriate technology for an early warning system are considered as parts of crucial efforts to reduce the risk of disasters. Unfortunately, the effectiveness in providing a hazard map and an early warning of disasters cannot be guaranteed due to less consideration on the social (including the cultural) conditions at the disaster area. Obviously, the need to integrate the social consideration into technical measures for disaster risk reduction should be addressed in order to assure the effectiveness in any implementation of such a hazard map and early warning system for disaster risk reduction [2].

\section{Concept of the hybrid socio-technical system}

To ensure the effectiveness in the implementation of any technology for disaster risk reduction, a combined (hybrid) system which considers both social and technical aspects needs to be developed. However, it is recommended to develop the existing indigenous or local technology through a community participation process. To allow such effective participation, a simplicity of the applied system and technology, and also the utilization of local material by local knowledge (local experts and local operators) through a local participation program must be considered. That is why it is important that the hybrid system should be performed with a low cost and simple technology or method which can be easily understood, operated and maintained by the local community, such as suggested by [3]. All of these concepts can be done only if the local community has been empowered. Therefore, the process of technological development can be carried out during or as a part of the process of community empowerment.

\section{Pilot implementation of the hybrid socio-technical system}

A hybrid socio-technical system has been implemented in one pilot area in Central Java, especially in Karanganyar Regency. This Regency is situated at the 
western slope of Lawu Volcano, in which $30 \%$ of the region is at high risk of landslides due to the high susceptibility condition (indicated by red [dark] color in the map of Figure 1), which is controlled by the geology and climate conditions, and also because of the high vulnerability of the socio-economical conditions in the landslide prone area [4].

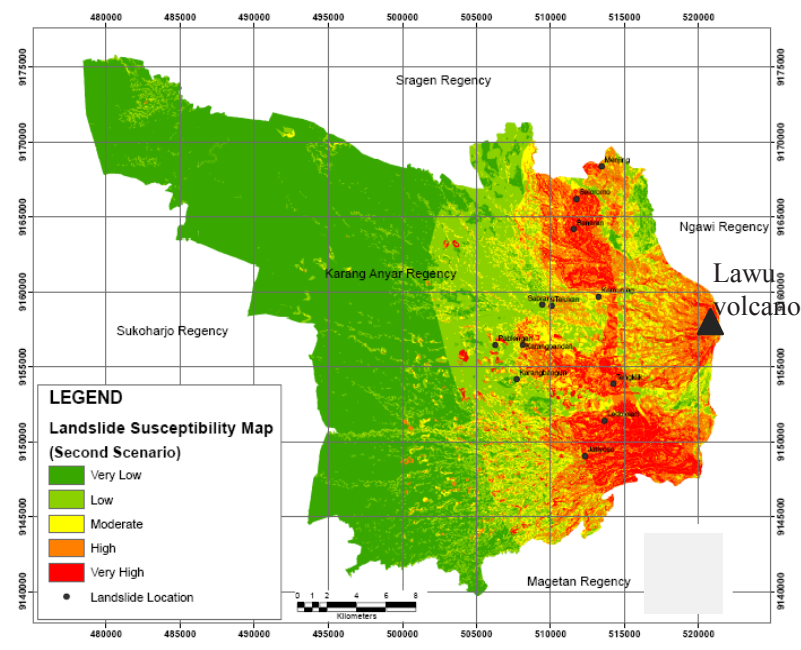

Figure 1: Landslide susceptibility map of Karanganyar Regency, Central Java, Indonesia, developed in regional scale of 1 : 100,000 [4].

Admittedly, it is impossible to change the natural (i.e. geology and climate) conditions in order to reduce the landslide susceptibility, but it will be more feasible to manage the social conditions for reducing socio-economical vulnerability in the landslide prone area. Therefore, landslide disaster risk reduction in the pilot study area was conducted by adaptive management as suggested by [5] and [6], which emphasized the improvement of community resilience, through the development of a hybrid socio- technical system.

\subsection{Social system development}

Development of the social component in the hybrid system was initiated by public education with various target groups such as women (as the key person in the family), teachers, children as well as the young and senior leaders. The local government of Karanganyar Regency also continuously and actively supported this social development program.

To ensure the effectiveness of public education and the development of the hybrid system, social survey was carried out. The base level of community understanding on landslide phenomena and its prevention method, together with the community perception and expectation on the proposed developed technology were also identified from the social survey. In addition, this survey found that most of the community members had been quite aware of the potential 
occurrence of landslides in the rainy season, because the landslide disasters have frequently struck their region, especially under the extreme weather conditions. Nevertheless, most of the community members preferred to remain living in their vulnerable region, instead of being relocated to the other safer areas. Obviously, the fertility of soil, the abundance of water resources, the beauty of mountainous panorama and the strong psychological engagement with their homeland or home-heritage, have strongly prevented their willingness to leave their dangerous homeland. Unfortunately, they do not have enough knowledge, skill and capacity to identify the zone (which part) in their village which is susceptible to landslides, the symptoms that landslide will occur, and also to decide about "what should" and "what should not do" for preventing the landslide. Thus, the capacity of the community to protect their life and environment needs to be further improved, with respect to the improvement of their resilient. Therefore, a simple hybrid socio-technical system for community-based landslide early warning was urgently required.

Again, the hybrid system was developed by the combination of social and technical systems. Initiated by public education and community participation, the social system was developed through the establishment of a community taskforce for disaster risk reduction at the village level (Figure 2), under coordination with the Agency for Disaster Management at the Regency level. This network is also linked to the local hospital (health center), the local army and police, and also the Search and Rescue Team (SAR team) at the local Regency.

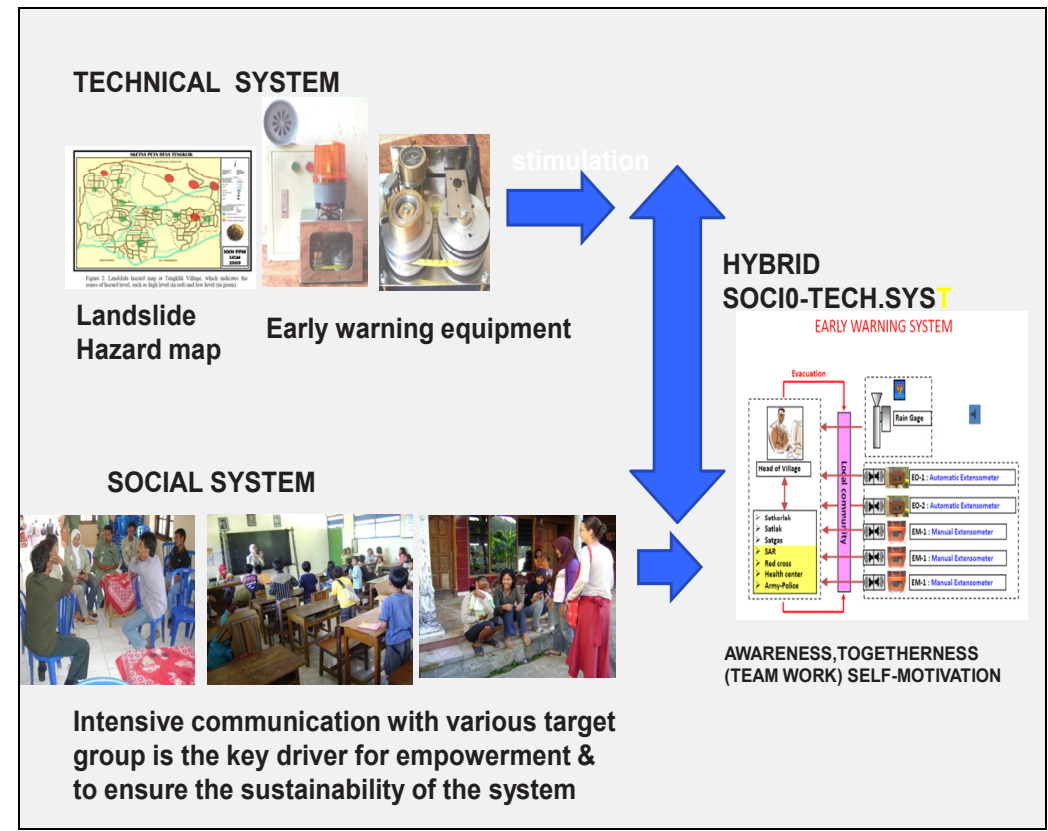

Figure 2: The concept and key components of a hybrid socio-technical system for landslide mitigation and an early warning system. 


\subsection{Technical system development}

Technical system development consists of development of a community landslide hazard map and an early warning system.

\subsubsection{Landslide hazard map}

The landslide hazard map was developed by applying the simple community hazard mapping method, suggested by [7]. The map was not prepared with the standard topographical map (standard technical map) which is usually conducted for hazard mapping. Learning that most of the technical map was not easy to be understood by the local community, thus in this community the hazard map of the village layout map, which was prepared by the local community, was applied. Such a map was presented without any contours, but mainly showing the layout of roads, rivers, houses and land farming areas which were very easy to be identified by the local community. Identification of the zone of high susceptible (red zone) and low susceptible or safe zone (green) for landslides was carried out by public participation with support by the adviser. This adviser should have enough knowledge for landslide hazard mapping. Figure 3 shows the landslide hazard map which was developed by the local community in Tengklik Village, Tawangmangu District, Karanganyar Regency, Central Java.

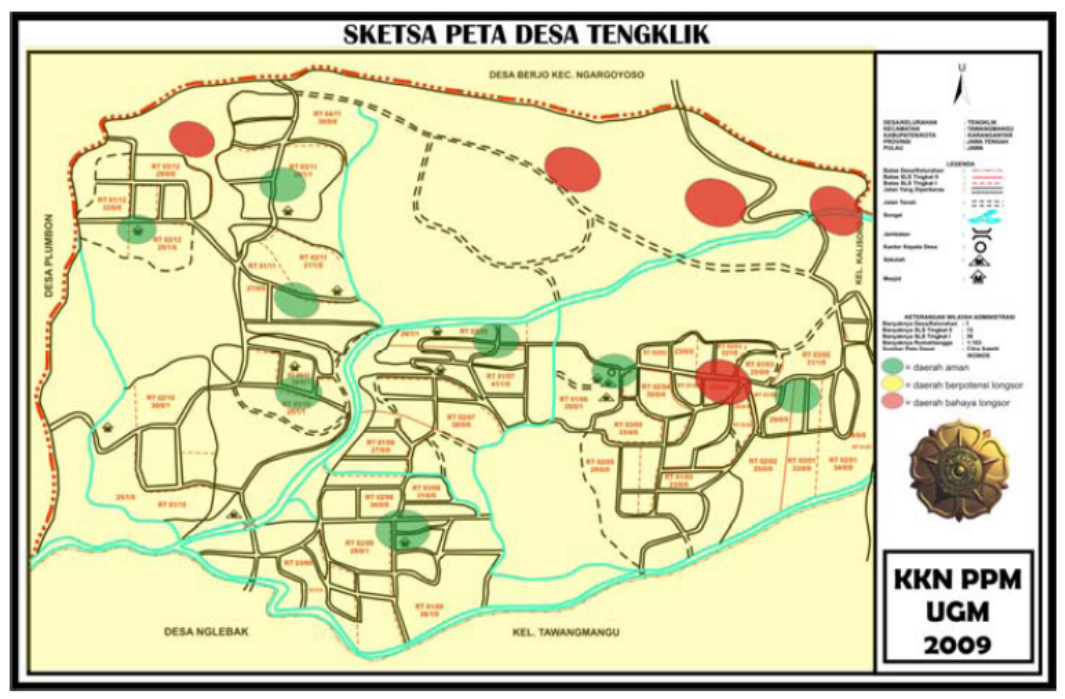

Figure 3: Community-based landslide hazard map of Tengklik village, Karanganyar Regency, central Java [7].

Through this approach and the simple method of landslide hazard mapping, the map will be easier to be understood and implemented by the local community. This map is also very important to decide how and where the early warning system should be developed. Therefore, the understanding and 
simplicity of the approach and method of mapping is the most critical part to guarantee the effectiveness of the disaster risk reduction program.

\subsubsection{Early warning system}

The technical system for landslide early warning was supported by several sets of equipment listed below:

1. Rain gauge ( $1 \mathrm{set})$ to monitor the rain precipitation in millimetres per hour.

2. Manual extensometers ( 5 sets) with the siren alarm generated by a dry battery, to monitor the landslide movement on the slope in $\mathrm{cm}$.

3. Solar panel ( 2 sets) to support the recharging of the dry battery.

The rain gauge was installed in the open space to record the rain precipitation which potentially induced land-sliding. Such a rain gauge was connected to an alarm and the alarm was set to be $\mathrm{ON}$ with a loud sound, when the accumulative rain infiltration had exceeded $100 \mathrm{~mm}$. This critical number of rain infiltration was set based on the previous research conducted by [8] and [9]. The alarm due to rain gauge warning was deliberately designed to raise the community alert, to immediately prepare for evacuation before the landslide event.

In many cases it is apparent that a crack at the ground surface always occurs prior to the landslide disaster event. Thus, the crack-extension can be used as the indicator of initial slope movement just before a landslide occurs. That is why monitoring on the crack extension was implemented to provide the warning system prior to the event of landslide disaster. Accordingly, the extensometer was designed in the pilot area to monitor the extension of the crack, by allowing the wire of such an extensometer to be pulled automatically across the crack, in response to the extension of crack induced by the slope movement. If the wire of the extensometer was pulled up to $4 \mathrm{~cm}$ length (this length was defined based on the previous empirical analysis at a similar susceptible landslide area), the connected alarm will give such a loud sound as the early warning to the community, so the community have to start to move away from the respective slope.

\section{Evaluation}

The establishment of a community task force for landslide disaster risk reduction at each village level is the most critical and important factor to ensure the effectiveness and sustainability of landslide mitigation. This task force had an important role as the driving agent in the empowerment and mitigation program. Since the hybrid socio-technical system which is supported by the community task force was applied in the pilot area in Ledoksari Village in 2008 and Tengklik Village in 2009, landslides occurred every rainy season every year without any victims and serious socio-economical losses. It is apparent that the community seems to be more capable to mitigate the landslides; the key person who was in charge for this mitigation program was invited to another landslide disaster area in Tanjungsani Village at Agam Regency, West Sumatera, to transfer his knowledge and experiences for the landslide mitigation in this region. Indeed, it is considered that this system is also very applicable to be 
developed in several other disaster areas in developing countries, which may need several adjustments with respect to the site social and environmental characteristics.

\section{Conclusion}

One of the most critical considerations of disaster risk reduction in developing countries is the assurance of effectiveness and sustainability of the disaster management in such a region. A combined (hybrid) socio-technical system has been introduced to solve such problems, by addressing the importance of community participation and the simplicity of technology for landslide hazard mapping and early warning. It is apparent that this innovative approach is quite significant to improve the effectiveness of the sustainable human and social development program. Indeed, the establishment of a community task force at the village level is very important to ensure the continuity and sustainability of this proposed system.

\section{Acknowledgements}

Special thanks are directed to the Indonesian Agency of National Disaster and the British Council Delphe Program for providing financial support to carry out this pilot study. The acknowledgments are also extended to Gadjah Mada University and the Ministry of National Education for the provision of academic facilities, as well as to the research assistant at the laboratory of Environmental Geology and the laboratory of Computation at Faculty of Engineering, Gadjah Mada University.

\section{References}

[1] Annoname, "Landslide disaster databased" Indonesian National Agency for Disaster Mitigation, 2009.

[2] Karnawati, D. Fathani, T.F. Andayani, B. Burton P.W. \&Sudarno, I, Strategic program for landslide disaster risk reduction; a lesson learned from Central Java, Indonesia. Disaster Management and Human Health Risk; Reducing Risk, Improving Outcomes. WIT Transactions on the Built Environment Transaction, K. Duncan and C.A. Brebbia, Ed. Southampton: WIT Press, 2009, pp. 115-126.

[3] Karnawati, D. Fathani T.F., Andayani, B. \& Suharto. The Hybrid SocioTechnical Approach as a Strategic Program for Social Development in Geodisaster Prone Area in Indonesia. Proc. of the World Science and Technology. Paris, June 2010.

[4] Karnawati, D. Fathani, T.F. Sudarno, I. Andayani, B. \& Burton, P.W., Landslide hazard and community-based risk reduction effort in Karanganyar and the surrounding area, Central Java, Indonesia. Proc. of the 7th Regional 
Conference of IAEG (Int. Assoc. of Engineering Geology). Chengdu, China, 9-11 September 2009, p.436-441.

[5] Andayani, B. Karnawati, D. \& Pramumijoyo, S., Institutional Frame Work for Community Empowerment Towards Landslide Mitigation and Risk Reduction in Indonesia. Proc. of the $1^{\text {st }}$ World Landslide Forum. Tokyo, Global Promotion Committee of the Int. Program on Landslide (IPL) ISDR, 2008, pp. 57-59.

[6] Karnawati, D. Fathani, T.F. Andayani, B. Burton P.W. \& Sudarno., I. Strategic Program for Landslide Disaster Risk Reduction; A Lesson Learned from Central Java, Indonesia. Disaster Management and Human Health Risk; Reducing Risk, Improving Outcomes. WIT Transactions on the Built Environment Transaction, K. Duncan and C.A. Brebbia, Ed. Southampton: WIT Press, 2009, pp. 115-126.

[7] Karnawati, D., W. Wilopo, and B. Andayani 2010. Development of Community Hazard Map for Landslide Risk Reduction". Proc. of the $11^{\text {th }}$ International Association of Engineering Geologist Congress, Auckland, New Zealand, September 5-10, 2010.

[8] D, Karnawati, T.F. Fathani, I. Sudarno, \& B. Andayani, "Development of community-based landslide early warning system in Indonesia (Published Conference Proceedings Style)," in Proceeding of the $1^{\text {st }}$ World Landslide Forum, Global Promotion Committee of The Int. Program on Landslide (IPL) - ISDR, Tokyo, 2008, pp. 305 - 308.

[9] Karnawati, D. Mechanism of Rain-induced Landslide in Allovanic and Halloysitic Soils in Java (Unpublished). Ph.D Dissertation. Leeds University, UK. 1996. 